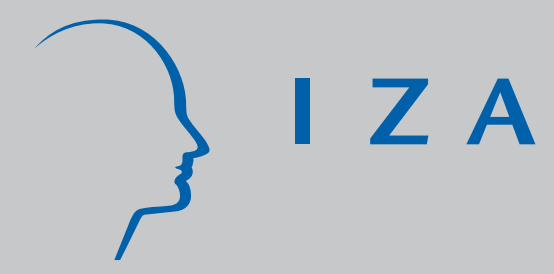

IZA DP No. 2430

Labour Market Regulation in the EU-15:

Causes and Consequences - A Survey

W. Stanley Siebert

November 2006 


\title{
Labour Market Regulation in the EU-15: Causes and Consequences - A Survey
}

\author{
W. Stanley Siebert \\ University of Birmingham \\ and IZA Bonn
}

\section{Discussion Paper No. 2430 \\ November 2006}

\author{
IZA \\ P.O. Box 7240 \\ 53072 Bonn \\ Germany \\ Phone: +49-228-3894-0 \\ Fax: +49-228-3894-180 \\ E-mail: iza@iza.org
}

\begin{abstract}
Any opinions expressed here are those of the author(s) and not those of the institute. Research disseminated by IZA may include views on policy, but the institute itself takes no institutional policy positions.

The Institute for the Study of Labor (IZA) in Bonn is a local and virtual international research center and a place of communication between science, politics and business. IZA is an independent nonprofit company supported by Deutsche Post World Net. The center is associated with the University of Bonn and offers a stimulating research environment through its research networks, research support, and visitors and doctoral programs. IZA engages in (i) original and internationally competitive research in all fields of labor economics, (ii) development of policy concepts, and (iii) dissemination of research results and concepts to the interested public.
\end{abstract}

IZA Discussion Papers often represent preliminary work and are circulated to encourage discussion. Citation of such a paper should account for its provisional character. A revised version may be available directly from the author. 
IZA Discussion Paper No. 2430

November 2006

\section{ABSTRACT}

\section{Labour Market Regulation in the EU-15: Causes and Consequences - A Survey}

Why should floors be set under wages and working conditions by labour market regulations? This paper finds that efficiency arguments are questionable, because of the disemployment effects of strict regulation. Regulation is better explained in terms of the choices of the employed semi- and unskilled worker group. This group contains the median voter, who rationally desires strict regulation to divert rent from other groups such as the skilled workers and the unemployed. Legal origin may also be important: some countries have fallen under the influence of the interventionist French (or German) legal tradition. Given a predisposition to intervene, these countries begin with some degree of labour regulation, which then creates its own constituency of rent protectors and rent growers.

JEL Classification: J38, J41, J58, J68, J83, K31

Keywords: labour market regulation, European Union, median voter, legal origin, minimum wages, working conditions floors, wage inequality, job opportunity inequality, long-term unemployment

Corresponding author:

W. Stanley Siebert

Business School

Birmingham University

University House

Edgbaston

Birmingham B15 2TT

United Kingdom

E-mail: w.s.siebert@bham.ac.uk

The author acknowledges comments from participants at the conference The Effect of Interjurisdictional Competition on Regulation, and particular help from Jean-Michel Josselin, Dennis Mueller, and Roland Vaubel, none of whom bears responsibility for the outcome. 


\section{LABOUR MARKET REGULATION IN THE EU-15: CAUSES AND CONSEQUENCES - A SURVEY}

\section{Introduction}

Labour market regulation sets floors under wages and working conditions. This paper discusses possible rationales for these floors: whether they are the outcome of efficiency considerations, or whether they are simply politically expedient (Saint-Paul, 2000). A third alternative is that labour market regulation is the outcome of a sort of path dependence, with French legal origin countries pre-disposed to regulate more strictly than English common law countries (Botero et al, 2004). England's common law is part of its exceptional "belief structure" (North, 1998, 28) which has led to the evolution of freedoms since the seventeenth century. Most of the large literature on labour market regulation considers its consequences, notably for unemployment, rather than its causes. However, if regulation increases unemployment, its efficiency is automatically called into question. Hence, our inquiry into causes will be assisted by a knowledge of effects.

The plan of the paper is as follows. In the next section we will set out the various dimensions of labour market regulation, how it varies among EU-15 countries, and over time. (In order to give a context to our EU analysis, we use the OECD group as comparators.) These are the phenomena for which we aim to find causes. Then, in succeeding sections, we will discuss the efficiency and public choice theories in turn. We will draw conclusions in the final section.

\section{Dimensions of labour market regulation}

To start with a broad view, we will find that, while labour regulation is manydimensioned, countries that are strict on one dimension tend to be strict on others. There are the policy "complementarities", which support the common idea of country or regional "models" ". Furthermore, while EU countries (apart from the UK, currently, at least) have strict regulation, the group of OECD countries as a whole vary widely in the extent of regulation, despite having similar levels of development. Hence there is something to explain. Finally, a country's regulatory stance does not change quickly. For example, the French law on extension of collective agreements dates from 1936 (Jefferys, 2003, 95). Changes in regulation often amount only to tweaking, as in the current round of reducing restrictions on employing temporary workers. Therefore, our theories of causation will need to explain why what is efficient (or politically expedient) in one country, is not so in others, and why the underlying causes - or responses - change so slowly.

The EU's stance on labour market regulation is grounded in the denial of the benefits of interjurisdictional competition. The many regulatory areas are shown in Table 1, which takes the 1989 Community Charter of Fundamental Social Rights of Workers as its starting point. This Charter marks a watershed (see Addison and Siebert, 1991 and 1994). On 15 March 1989, the European Parliament adopted a resolution on this Charter, calling for:

"the adoption at Community level of the fundamental social rights which should not be jeopardised because of the pressure of competition or the search for increased

\footnotetext{
${ }^{1}$ Though the straight right-left characterisation, with weak employment protection/low taxes versus the opposite is thought to be too simple by some (Amable and Gatti, 2004), who also distinguish a "flexicurity" model (Gorter, 2000, 188) with weak employment protection and high taxes, to which the Netherlands and Denmark (see OECD, 2004, 95) are thought to belong
} 
competitiveness, and could be taken as the basis for the dialogue between

management and labour" (EU, 2005).

Thus, the expansion of EU labour regulation was born out of a concern that the increased competition resulting from completion of the single market in 1992 would lead to a race to the bottom in labour standards.

The Charter became the Social Chapter of the Treaty of Maastricht (1997), and has been incorporated into the draft EU Treaty, and developed considerably in several areas contested by the UK, which has most to change. Table 1 gives the situation. The main contested areas are "atypical work" (part-timers and temporary workers, row b), limitation of working hours (row c), discrimination - which has even been extended to "age" - and company works councils. The UK position is not simply due to Thatcherism, since the Blair government has also been active (see The Times, 2005), for example in preserving the UK's opt-out from the 48 hour maximum working week (row c1). The Blair government (Financial Times 2005a) has also been trying to preserve the UK's agency work companies from the restrictive agency workers directive (row b). Further, it is thought (Financial Times 2005b) that the directive on company works councils (row h2) has been "aimed squarely at Britain and Ireland", as the only members of the EU-15 without such councils playing a role in employment protection. The UK really is different, and has more in common with other Anglophone countries, as we will see. So far, interjurisdictional competition within the EU has mainly been between the UK and the rest.

The body of labour legislation in Table 1, wide though it may be, is as interesting for what it does not contain, as for what it does. It contains nothing on wage floors. The Commission has confined itself to anodyne Opinions on "equitable wages". Wage floors can be set by minimum wages, or by extension of collective agreements (row b). Such extension is common in the EU (Siebert, 1997, 230). In principle, social security benefits (row d) can also set a floor, but little has been done at EU level here either. Perhaps the UK falling into line by establishing a minimum wage in 1999 has pre-empted moves towards a directive. Perhaps, as well, the UK, having had a disastrous flirtation with extension of collective agreements under Old Labour in the 1970s, is not yet thought ready to be brought into the fold.

Still, the fact that wages are not set by national sectoral agreements will leave the UK's wages more flexible, and paradoxically should reduce opposition to further EU legislation raising working conditions. Nickell and Quintini (2003) have found that the proportion of job stayers taking hourly nominal wage cuts is as high as $15-20 \%$ every year. The implication is that hikes in job conditions have less effect, since wages simply fall to reflect the better conditions (Summers, 1989), leaving profitability unaffected.

While more research remains to be done on wage flexibility in other EU countries, it certainly seems that wage compression is considerable here, and this compression is related to extended collective agreements. Some evidence is given in Figure 1, which measures wage compression by the ratio of the $90^{\text {th }}$ to the $10^{\text {th }}$ earning decile, and extension of collective agreements by collective bargaining coverage. The low coverage countries such as the UK, the US, Ireland and Canada have higher inequality than the high coverage (EU) countries making up the mass of the points at the lower right. Still, the compression of wage differentials in most continental European states - a compression that has malign effects on unemployment, as we will see - cannot be blamed on the EU, which has not legislated in this area. However, it can be said that the EU 
stance such as the "right to fair and just working conditions" in the ill-fated Constitutional draft (article11-91) is certainly in the direction of wage compression and inflexibility.

Finally, on the subject of wage compression, it is worth considering Koeniger et al's (2004) panel study of the 90/10 wage differential of 11 OECD countries over 197399. They use the fixed effect approach, and control for employment protection, union density, bargaining coordination, minimum wage laws, taxation, welfare benefits, the relative unemployment rate of unskilled versus skilled, and trade and technology shocks. One thing they find, is that trade widens the 90/10 differential, ceteris paribus. This finding goes against the popular argument (e.g., Agell, 1999) that trade openness increases people's demand for labour regulation, which is therefore an efficient response to the risks of trade.

The most important variable by far in Koeniger et al's (2004) analysis is employment protection, which strongly compresses wage differentials. High welfare benefits, union density and minimum wage indicators also compress differentials, as may be expected. We will consider employment protection in more detail below. Suffice it to say here that strict employment protection is likely to be most costly for the unskilled, and in a competitive market thus to widen wage differentials. The fact that the reverse effect is found implies that trade union power is using employment protection as a hold-up threat to increase unskilled wages at the expense of unskilled unemployment. Therefore, there is evidence here against efficiency explanations of regulation, though we will need to consider the research on unemployment effects of labour market regulation (see below).

To analyse working conditions regulation, summary measures have needed to be developed. Lazear (1990) famously developed an index based on the number of months of severance pay or notice a blue collar worker with 10 years of service would receive for termination without "cause". Such an index has the advantage of being cardinal, and time-varying (from 1956 to 1984). However, it is narrow, and Grubb and Wells (1993) developed a wider index including not only employment protection, but also restrictions on working hours and restrictions on temporary workers. They assigned ordinal levels of strictness to the various laws, and then averaged the results together to build up an index of "restrictions on overall employee work". The resulting index has the disadvantage of not being really cardinal, but at least is broad-based.

The approach of "scoring" various laws according to their strictness, then averaging the results together has been followed in subsequent OECD work (OECD, 1999, and 2004) - including work on product market regulation (Nicoletti et al, 2001). Blanchard and Wolfers (2000) have even linked together the Lazear and OECD employment protection indices to make a time series which is regularly used in empirical work (see Koeniger et al 2004, and Daniel and Siebert, 2005). Moreover, Botero et al (2004) have recently expanded the countries covered, and the types of regulation. They have developed indices not only of restrictions on overall employee work (including employment protection, hours restrictions, and temporary work restrictions), but also collective bargaining protection, and generosity of social security benefits for unemployment, sickness and old age. These indices are available for 86 countries, but are not time-varying.

Figures 2 to 4 illustrate aspects of this work. Figure 2 contrasts the OECD employment protection law (EPL) measure with Lazear's. We see an association, but it is 
far from perfect. The two indices agree that Italy, Norway and Spain are most regulated, with the UK and the US least. However, the OECD index puts Portugal and Sweden as much more strictly regulated than does Lazear. Thus we see that the force of employment protection legislation cannot be measured with precision. In empirical work, therefore, we would expect the coefficient on the employment protection indicator to be biased towards zero because of measurement error.

Figure 3 compares employment protection laws with collective bargaining laws. On the vertical axis, the Botero et al (2004) employment protection measure is given, for a change. (This index correlates well, 0.754, with the OECD index of Figure 2, though the Netherlands is rated as very strict here, which is difficult for the "flexicurity" view of that country.). The horizontal axis gives the Botero et al measure of protection for collective bargaining protection. This measure is broader than the collective agreement coverage measure we have already come across (Figure 1), though the two are obviously associated $(\mathrm{r}=0.409, \mathrm{p}<.07)$. France is rated as most protective on this index, because employers cannot replace strikers, collective agreements are routinely extended, unofficial strikes are lawful, and workers councils are mandated ${ }^{2}$. The UK is least protective. As can be seen, strict employment protection and strict collective bargaining protection tend to go together, notwithstanding strange outliers like Japan and Finland. There might be a causal connection here, or both aspects of regulation could be the result of a third factor, such as legal origin, as discussed below.

Figure 4 presents a view of the correlation between strictness of employment protection and generosity of unemployment benefits. These two might be thought (see Boeri et al, 2004) to be alternative forms of insurance against job loss, though with different distributional outcomes. The unemployed will prefer unemployment benefits to employment protection, which reduces their chances of finding a job. However, the currently employed will tend to have the opposite view (not necessarily very strongly, since unemployment benefits also drive up wages ${ }^{3}$ ). In fact, the picture presented in Figure 4 is one of complementarity, with Portugal, for example, being high on both, and New Zealand low on both. Of course, alternative measures of unemployment benefit generosity can be chosen. Most popular is the OECD's unemployment benefit replacement rate (see Grubb, 2005), though some versions ignore housing subsidies for the unemployed which are important in the UK. In any case, use of an OECD replacement rate measure in place of the Botero et al index still gives a positive correlation with employment protection. We are left, therefore, with the fact that employment protection and collective bargaining protection tend to march quite tightly together, with unemployment benefit generosity in a somewhat looser formation, but still part of the pack.

\section{Efficiency}

The question of whether the types of labour market regulation reviewed above are a response to market failure, and are therefore efficient, is most simply answered by looking for effects on employment. If employment increases, we have efficiency in the sense that the gains of the gainers will be greater than the losses of the losers, if any - that is, a (potential) Pareto improvement. If it decreases, however, the gains of the gainers will

\footnotetext{
${ }^{2}$ Germany is clearly similar, though with the difference that unofficial strikes are not allowed. On the other hand, workers and/or unions have the right to appoint directors to the board.

${ }^{3}$ See Amable and Gatti, 2004 for a model. However, deriving conditions under which employment protection and unemployment benefits are substitutes or complements or neither is not simple - see Saint Paul (2001, chapter 9).
} 
be less than the losses of the losers. For the efficiency argument to hold, it would then be necessary to argue that the gainers are more deserving in some sense than the losers, which economists are understandably reluctant to do. Positive, or at least, not negative, employment effects are thus central to the efficiency case. Accordingly, researchers have from the first searched for these effects.

However, to get to the bottom of things, it is necessary to disaggregate employment and unemployment. It is possible for the overall unemployment rate to remain constant, even as its long-term component increases. Hence we need to consider the long-term unemployment rate as well as the overall unemployment rate. Equally, we need to disaggregate employment, and consider what happens to young and old workers, as well as the majority "prime age" group. But it has taken research some time to get to this point, in fact, since for simplicity the early models (e.g., Nickell, 1986) began with a homogeneous labour assumption. (It was also assumed that unions, as a sort of "social partner", represented all workers.) Much was then made of the fact that the theoretical predictions for employment protection were ambiguous, and that this ambiguity was borne out in empirical work.

Yet a different picture appears if one disaggregates, because wage and working conditions floors have most impact on the least productive. Simply put, employers become more "choosy" when selecting workers if there is an increase in firing costs, provided that the increase is coupled with inflexible wages. The inflexible wages proviso ensures that wages cannot fall to reflect the value of the extra job security to the workers, that is, it prevents workers and firms "contracting around" the employment protection constraint. On this reasoning, strict employment protection accompanied by tight wage differentials due to state support for collective bargaining (the two go together, as we have seen) can be expected to cause a rise in hiring standards. There will be less hiring and less quitting, and long-term unemployment should increase (for models, see Boeri 1998; Guelfi 2004). Employers should spend more on recruiting, and emphasise education. They should also avoid the workers at the two ends of the age distribution, thereby pushing up unemployment for the young and early retirement for the old. The French have an expression for this phenomenon: "une seule generation travaille a la fois". Note how union power and employment protection work together.

It would be difficult to argue that these kinds of displacement effects are efficient but do they occur? Table 2 provides some recent OECD evidence, and Table 3 considers evidence from a company hiring standards study within the EU.

Table 2 summarises three studies which tell broadly the same story, namely, that employment protection laws displace outsider groups (the young and old), and lengthen the duration of unemployment. First, the study in Panel A by Bertola et al (2004) uses a long panel of OECD countries to analyse employment/population ratios by age and gender. Admittedly, we see here that employment protection is generally insignificant (only for males 55+ does it adversely shift the ratio). However, the three union variables (density, agreement coverage, and bargaining coordination) push down the ratio of young and old worker groups relative to the prime age. The next rows take unemployment as the dependent variable, and here employment protection plays a more important role, increasing unemployment for three of the groups - and reducing it for none. However, the three union variables are not as adverse for unemployment as might be expected. 
Next, Panel B takes the 2004 OECD studies, one of which considers long-term unemployment. Here we see that employment protection is significantly positively related to long-term unemployment, ceteris paribus. However, in this case the union variables are insignificant. The second study analyses union effects on employment/population ratios. We see that union effects are adverse for both young and old men, relative to prime age men. However, unions are positive for prime age women, which may indicate that unions are no longer so male dominated.

Panel C summarise Botero et al's (2004) results. Here the dataset is quite different, being a cross section of 85 countries throughout the world. These are much simpler regressions than the ones we have been considering, due to data limitations. Still, this broader population of countries gives a nice contrast to the OECD group. We see that the employment laws index (the same as that graphed in Figure 3) again indicates adverse effects of employment protection, reducing labourforce participation and employment-population rates of both men and women, and raising the unemployment rate. The bargaining laws index (again in Figure 3) also indicates adverse effects of union power.

The final Panel D give an interesting glimpse of the trade-off between wage compression and job opportunities. As can be seen, the simple correlation (allowing for country and time-period fixed effects) between the 90/10 earnings ratio and unemployment is highly significant, and negative, -0.44 . Similarly the correlation between the 90/10 ratio and the employment/population ratio is significantly positive, 0.45. The other correlations show that the employment opportunities of both young and old men decline relative to the prime age group as the 90/10 ratio falls, though opportunities of women apparently increase. Therefore, it seems that earnings equality is bought at the cost of job opportunity inequality.

Finally, let us turn to Table 3, which uses a completely different type of data, micro-economic data gathered from the personnel records of 11 firms in the EU and USA. The observations are formed from the characteristics of production worker recruits hired by the firms each year from 1975-95. Specifically, the mean and standard deviation of starting age and education are calculated for each firm and each year. If strict employment protection makes employers more choosy, the standard deviation of starting age should decline with employment protection, as firms avoid both young and old workers, who might be more risky than the prime age groups. As can be seen, the employment protection variable enters the standard deviation of starting age equation with the predicted negative coefficient, -9.12 . A further prediction is that firms should choose more highly educated workers. Again, this prediction is borne out, since the average education equation has a positive coefficient on the employment protection variable, 2.35. The other variables listed, union density and the tax wedge, apparently do not matter so much at the firm level.

In sum, labour market regulation designed to improve working conditions and strengthen collective bargaining obviously does so, but at the expense of reduced job opportunities for outsider groups: the young, the old, the inexperienced. Furthermore, it drives up long-term unemployment, and youth unemployment. Thus, the picture is not one of efficiency and win-win. Rather, semi-skilled workers gain at the expense of others, who are less-skilled. The "cause" of labour market regulation, therefore, seems more likely to be acts of the (employed) median voter, which is the public choice theory, to which we now turn. 


\section{Public Choice}

We now consider labour regulation as the outcome of distributional conflict. These waters are relatively uncharted, because surprisingly few authors have considered distributional conflict in detail in this area. (A long time ago, however, Becker (1956) showed that white workers can use discrimination to raise their pay at the expense of capitalists and black workers.) The lack of interest in distribution can perhaps be explained by the popular view that distributive conflict takes place simply between capital and labour, i.e., unions are a "sword of justice". Redistributive effects of labour regulation are then obviously from the rich to the poor, and can be justified by "social concerns" (Gray, 1995, 314). In other words, the popular, if mistaken, view is that the cause of labour regulation is obvious: to right wrongs.

However, as Saint-Paul says $(2000,5)$, the conflict which matters is that between different groups of workers, not between capital and labour ${ }^{4}$ The median voter will be drawn from the majority (employed) semi- and unskilled group, which constructs laws to benefit itself. Put simply, this group promotes collective bargaining and employment protection laws to pump up its wages and conditions, and drives unskilled workers into unemployment or temporary work. This redistribution is highly inefficient, since it requires part of the workforce to be idle, and excludes the poorest from the redistribution. The same transfer, but at less cost, could be achieved via the tax system, and we will need to explain why this course is not pursued. But first, it is worth considering the various interest groups and their possible motivations in more detail.

Table 4 synthesises Saint-Paul's various models of the interest groups whose conflict drives labour market regulation. In the version shown, there are five groups, and three types of labour regulation: minimum wage laws (in which we can include minima imposed by collective agreements), employment protection laws, and welfare benefits. To this list we should add a fourth area: laws strengthening trade unions and collective agreements. For simplicity, we can simply think of strong trade unions as an aspect of high minimum wages. However, strong trade unions may not be all that important to the semi- and unskilled worker groups (whom they mainly represent), if these groups wield political power and can change the regulatory system appropriately.

In the first row, we consider the skilled worker group, which comprises managers and professionals at the top of the wage distribution. Their interest is simply to oppose a minimum wage (including any minima imposed by collective agreements). A minimum wage cannot raise their pay, which is far above any minimum, and moreover it reduces the employment of complementary unskilled workers.

However, as regards employment protection, the attitude of the skilled group may be ambivalent. On the one hand, the market for their type of work is quite competitive, with flexible wages (Saint-Paul, 2000, 5) ${ }^{5}$. Hence, they do not benefit directly from

\footnotetext{
${ }^{4}$ A clear example of such a conflict between workers is in apartheid-era South Africa. The strongest supporters of the "colour bar" exclusion of blacks from jobs were unskilled white workers in government, on the railways and in the mines (Siebert, 1986). The conflict was between white and black workers, with (white) capitalists siding with the blacks, exactly in line with Becker's model.

${ }^{5}$ In Saint-Paul's model, the skilled labour market is competitive; the unskilled is uncompetitive with unresponsive wages, and involuntary unemployment. Interestingly, Teulings and Hartog $(1998,262)$ believe exactly the opposite: "High skilled workers in high rent industries [in the USA] are largely safeguarded from the hazards of economic fluctuations, while low skill workers in low rent industries get the full load".
} 
employment protection which, after all, is designed to protect rents. On the other hand, permitting employment protection for the (employed) semi- and unskilled groups might reduce calls for more wholesale redistribution via heavier taxation of the rich (Saint-Paul, 2000, 68ff). In a sense, the skilled group allows the unskilled groups their job protection, and so reduces their jealousy. (Though, as Figure 4 shows, high employment protection generally goes with high unemployment benefits, and thus high taxes, so this strategy does not seem very successful.)

Finishing the top row, skilled workers are against high unemployment benefits because high benefits will disproportionately raise their taxes. Moreover, high benefits reduce complementary unskilled employment. This effect occurs most obviously because high benefits will subsidise longer unemployment spells. Also, high benefits will raise the outside option for unions representing semi- and unskilled workers, improve their wages, and further act to reduce unskilled employment.

The second row shows the position for the semi- and unskilled group which makes up the lower end of the wage distribution. This group is vital because it contains the median voter. The workers here are in favour of a high minimum wage because it may be paid to them. The minimum (plus minimums brought through strong unions and extended agreements) will also push some unskilled workers into unemployment. These workers are substitutes, and so their exclusion further raises the pay of the employed remainder.

Assuming they are receiving rents, the semi- and unskilled group will also be in favour of employment protection. Rents are important for distributional conflict models. Everyone wishes to grow and protect their rent. In earlier versions (e.g., Saint-Paul 1996 and 1997), the source of these rents is union power and other obstacles to competition such as state-run enterprise and tariffs. (One may add takeover obstacles due to nontransparent corporate governance rules such as prevail in French civil code oriented countries - Laporta et al, 1998.) In the more recent model (Saint-Paul, 2002), rent is identified with match-specific human capital, which grows with tenure. The obstacles to competition identified above are meant to allow workers to appropriate the returns to this specific capital. The new model allows a distinction to be made between short and long tenure workers (the youth/prime-age distinction we have already seen), with short tenure workers being less in favour of protection. Also, the match-specific human capital idea provides a further way for employment protection to create path dependence. Once employment protection is begun, it raises worker tenure, which in turn swells the constituency of workers wanting more protection. Thus, (employed) semi- and unskilled workers use employment protection to protect their rents, and then by reducing competition from the unemployed, employment protection grows the rent.

The semi- and unskilled group also favour high unemployment benefits. One obvious reason is because they might become unemployed. An additional reason is that high benefits increase workers' outside option, and thereby the wage. Saint-Paul (2000, 154) even notes circumstances in which the employed prefer higher unemployment benefits than the unemployed. Since high unemployment benefits push up wages, they reduce hiring rates - which helps the employed and hurts the unemployed. Hence the unemployed and the employed may be on paradoxical opposite sides of the fence as regards high unemployment benefits. 
The third and fourth rows of Table 4 take in the unemployed, with a distinction made between the short-term and the long-term unemployed. The short-term unemployed are close to finding a job, whereas the long-term unemployed have deep-seated problems. There is no reason for the long-term unemployed to want high minimum wages or strict job protection, both of which reduce their already slim chances of landing a job. The short-term unemployed should take an intermediate position on these policies, from which they could benefit once in a job. Finally, on our previous arguments, neither should want too high an unemployment benefit level, though presumably the more discouraged the long-term unemployed become, the higher the benefits they would vote for.

Finally, consider the capitalists. Worker rent growing and protecting policies obviously reduce profits, if unexpected. Admittedly, in the longer run, projects will only be taken on if they can make a profit given the current labour regulation, so capitalists may tend to be somewhat indifferent. However, the long run might be some time coming. Moreover, regulation breeds regulation. So capitalists would rationally vote against all these policies.

Looking at Table 4, the surprising thing is that every country is not strictly regulated. With the sizes of the five interest groups as illustrated, it is plain that the interests of the employed semi- and unskilled group will dominate in any voting. It is true, voting might not be all-important, and lobbying could have a role to play (Becker, 1983). Here, the capitalists could punch above their weight, since they are well organised. On the other hand, the employed worker groups also have skilful trade union lobbyists who will act as a countervailing force. The unemployed, while quite numerous are too heterogeneous to form a coherent lobby, and in any case, the short-term unemployed might well be ambivalent. Therefore, the move towards strict labour regulation would seem unstoppable. But why, then, are some countries further down this road than others?

The type of democracy can make a difference. It has been demonstrated that proportional representation (PR) electoral systems, as are the norm in most EU states (though not France itself!), lead to more corruption than first-past-the-post systems as in the UK (Persson and Tabellini 2003, Ch. 7). Corruption is likely to encourage rentseeking, which as we have seen is necessary for the median voter to gain from employment protection regulation. Corruption may arise within PR (Mueller, 2003, 545) because of the weaker accountability of politicians in the typical PR list system where voters can only choose among parties. Also, the PR system gives corrupting powers of patronage to the party leadership, which controls the list. Even better than first-past-thepost in this respect might be direct representation via referenda. Thus, Feld (2005) shows that Swiss cantons with more direct democracy have less powerful interest groups (fewer licensing requirements for professions). Frey and Stutzer (2000) back up this point by demonstrating that cantons with more direct representation have populations with higher self-reported happiness.

If we are looking for ultimate causes, the legal origin theory put forward by Botero et al (2004) makes sense, and can be mated with Saint-Paul's public choice theory quite well. In the beginning comes the legal origin. The French civil law and the English common law are the main origins. "Countries have regulatory styles shaped in part by their legal systems, and therefore societies that regulate one activity are also expected to regulate others” (Botero et al, 2004, 1371). On the continent, centuries of absolute government gave rise to a tradition of powerful administrative authority (Hayek, 1960, 193), culminating in Napoleon's civil code - and manifested, for example, today in 
France's 2000 page Code du Travail (Jefferys, 2003, 12). As noted at the outset North (1998) agrees with this view. On the other hand, Josselin and Marciano (2002) take the view that the Napoleonic Code and English common law are not very different, since the Code merely codified common laws and practices. But this view ignores the fact that the judge and jury in the common law system permit the law to develop without central government control. However, central government control is the core of the Code system. Moreover, we see a marked difference between Anglophone and continental European states in the extent of their regulation. If efficiency is not the answer, then what is?

Glaeser and Shliefer (2002) argue that the different legal traditions themselves are the efficient outcome of different environments in the $12^{\text {th }}$ and $13^{\text {th }}$ centuries. England was more peaceful than France, and the king less powerful, so judicial independence was able to grow in England. In France, the judge-inquisitor system developed, both to protect the judges against powerful nobles, and to allow the king to control judges. Thus, in the English common law tradition statute law has come merely to supplement the unwritten law, and the judge's decisions effectively make law, which is contrary to the principles of the civil code system. Indeed, the common law reliance on judicial precedent is a "key guarantee of freedom” say Glaeser and Shliefer $(2002,1220)$. The evolution of judicial precedent, together with the jury system ${ }^{6}$, can be seen to put individualistic relations above state "plans"7

French legal origin states can thus be said to be "predisposed" to regulate (because central government controls the legal system), and here Saint-Paul's theory can be brought in. What Saint-Paul's theory suggests is that regulatory policies a) tend to be complementary, and b) that they develop path dependence. Thus, collective agreement extension laws give rise to rents which employment protection laws complement, by protecting the rents. Again, employment protection laws, once set up, build up a constituency dependent on such protection and further advancing it - path dependence. Above, we mentioned impediments to competition, such as strong unions, product market regulation, or tariffs. These factors make labour demand inelastic, and raise the payoff from labour market regulation from insider groups. However, these factors are not truly exogenous, but are themselves determined by legal origin. In fact, from the small seed of legal origin, the whole panoply of labour regulation may be said to grow.

To test arguments about the importance of legal origin, Djankov et al (2003) have developed legal formalism indices for 109 countries. At the ideal, informal, end they put the "neighbour" model, where one neighbour resolves a dispute between two others using common sense and custom - lay judges, broad principles, juries and oral argument. At the other extreme, they put professional judge-inquisitors, legal codes, written records, and regular appeals. They (2003, 459ff) collect data from law firms in each country on these procedural variables in the case of hypothetical default in two simple cases, a bounced cheque, and the eviction of a non-paying tenant. The aim of the index is to se how far procedure in a given country diverges from the neighbour model. The authors also collect data on how long these two types of case take to settle (for example 60 days in New

\footnotetext{
${ }^{6}$ Adam Smith in his Lectures on Jurisprudence $(1766,71)$ emphasises the role of English law juries: "The law of England, always the friend of liberty, deserves praise in no instance more than in the careful provision of impartial juries” (Meek et al, eds.,1982, 425).

${ }^{7}$ Hayek $(1960,56)$ speaks of an "essentially empiricist" view of the world in England ("trial and error procedure"), and a "rationalist" approach in France ("an enforced solely valid pattern"), and goes on: "The British philosophers laid the foundation of a profound and essentially valid theory, while the rationalist school was simply and completely wrong”.
} 
Zealand for the bounced cheque, as against 645 in Italy $\left.{ }^{8}\right)$. Put simply, procedural formality means, “worse contracting institutions” (Acemoglu and Johnson, 2003).

Figure 5 gives a scatter diagram for a legal formalism index against employment protection (formalism here being the average of four measures developed by Djankov et al). French legal origin countries are most formal, averaging 13.5 on this index, with English legal origin countries averaging only 2.5. German (11.5), and Scandinavian (5.0) come in between. Formalism gives a good explanation of OECD country variation in employment protection. As can be seen, the scatter is tight $(\mathrm{r}=0.642)$, and is in fact much tighter than for other variables such as trade union density $(\mathrm{r}=0.324)$, or left-wing orientation of government $(\mathrm{r}=0.331)$. (Correlation of the formalism index with union protection (Figure 3 ) is also good, with $r=0.712$.) However, there is a much lower correlation between formalism and generosity of unemployment benefits ( $\mathrm{r}=0.297)$, and essentially no correlation with a wider measure of welfare generosity, including old-age pensions ( $\mathrm{r}=-.118)$. This pattern is not surprising since, as we have seen, while employment protection and collective bargaining protection go together across countries, welfare benefits do not. Nevertheless, the point remains that formalism is closely associated with employment protection, and collective bargaining protection.

The legal origin theory has been criticised (Botero et al, 2004, 1365) as standing in for an unmeasured third factor, in particular the electorate's social-democratic "tastes", wherever these come from. In answer to this criticism, Botero et al show that legal origin also predicts employment and union protection well even among their sample of nondemocratic countries. Path dependence is influential even for dictators it would seem.

Acemoglu and Johnson (2003), have also criticised the legal origin theory, as being secondary to democratic institutions. Looking at a world-wide set of countries, they show that growth and employment are more dependent upon whether democratic institutions have taken root, than on legal formalism. In turn, whether democratic institutions take root is dependent upon their colonial history, and specifically whether colonists settled and brought their home country institutions, or merely exploited the colony. Their favourite variable is settler mortality in the 1500s because mortality determined whether colonists settled or not. Democratic rights protect contracting parties against expropriation by the state, whereas, they say, legal formalism merely lowers contracting costs. However, this objection does not apply to the EU/OECD group on which we are focussing here, since all are currently democratic ${ }^{9}$. In fact, we cannot even test the argument about the importance of colonists settling in the EU/OECD context, since these are all mother countries. Democracy versus legal origin remains only an intriguing possibility, therefore.

\section{Conclusions}

Labour market regulation in the EU is extensive and expanding. It takes two forms. First, there is the setting of floors to working conditions, which is the main area for directives, as shown in Table 1. Second, there is the setting of wage floors via minimum wages and, more importantly, extended collective agreements. This form appears currently to be left to the member states. Figure 1 demonstrates how broad is the coverage of collective

\footnotetext{
${ }^{8}$ The mean for English legal origin countries is 176 days, for socialist 327 days, for French 272 days, for German 193 days, and for Scandinavian 234 days (Djankov et al, 2003, Table V)

${ }^{9}$ However, the democracies of Spain, Portugal, France and Germany are new and (with the exception of France) use proportional representation, which suggests less accountability of politicians and more rent for protected worker groups, as already noted.
} 
agreement in the core EU countries. High floors under working conditions and under wages tend to go together (Figure 3).

The UK has historically been the odd man out in the EU, in the south-west corner of Figure 3, along with other Anglophone countries. The core of the EU is in the northeast corner, suspicious of the power of competition to drive labour standards down. As we have seen, it is this suspicion which underlay the drawing up of the 1989 Charter of Fundamental Social Rights of Workers, which was incorporated into the 1993 Social Chapter of Maastricht and the draft EU Treaty. The UK is now being brought into line, with proposals to impose shorter working hours, reduce the temporary work agency industry (REC, 2002), and impose formal worker consultation via company works councils. Inter-jurisdictional competition is being eliminated in favour of strict labour regulation.

We have seen that the efficiency arguments for strict labour regulation are questionable, because of disemployment effects. Careful statistical studies with many controls indicate that such regulation reduces job opportunities for outsider groups: the young, the old and the inexperienced. It also drives up long-term unemployment. Labour regulation thus causes redistribution within worker groups, with the least advantaged being excluded from the redistribution. Wage equality is bought at the expense of job opportunity equality.

We have surveyed Saint-Paul's theories of labour regulation as redistribution in detail (Table 4). These theories quite reasonably put the employed semi- and unskilled worker at the centre, because this group contains the median voter. This group is shown rationally to desire strict labour regulation with which it diverts rent from skilled workers, the unemployed, and the capitalists (who, however, being more mobile, are difficult targets). Out of this world come the policy complementarities that we have observed. Also, and most important, comes path dependence.

Path dependence - perhaps coupled with proportional representation - is important. It provides a way of explaining why some countries are so much further down the labour regulation road than others, even though all have broadly the same type of median voter. Here, we have put Saint-Paul's model together with Botero et al's (2004) legal origin model. The legal origin comes first: some countries have fallen under the influence of the interventionist French legal tradition, and have continued that way because of the high transactions costs associated with changing. (Indeed, the interventionist "rational” tradition might even produce proportional representation: PR has not evolved organically, as has the UK's first-past-the-post, but is the product of a kind of rationalism.) Given a predisposition to intervene, these countries begin with some degree of labour market regulation, which then creates its own constituency of rent protectors. Path dependency takes over, and regulation grows.

We have noted that the UK's wage behaviour is still quite flexible, which is fortunate. (The UK's new minimum wage system affects only a minority.) If wages can flex downwards as labour standards are hiked upwards, not much damage will be done. Interjurisdictional competition will continue for the time being. But crocodile tears should not be shed for the unemployed while labour regulation is made ever stronger. 


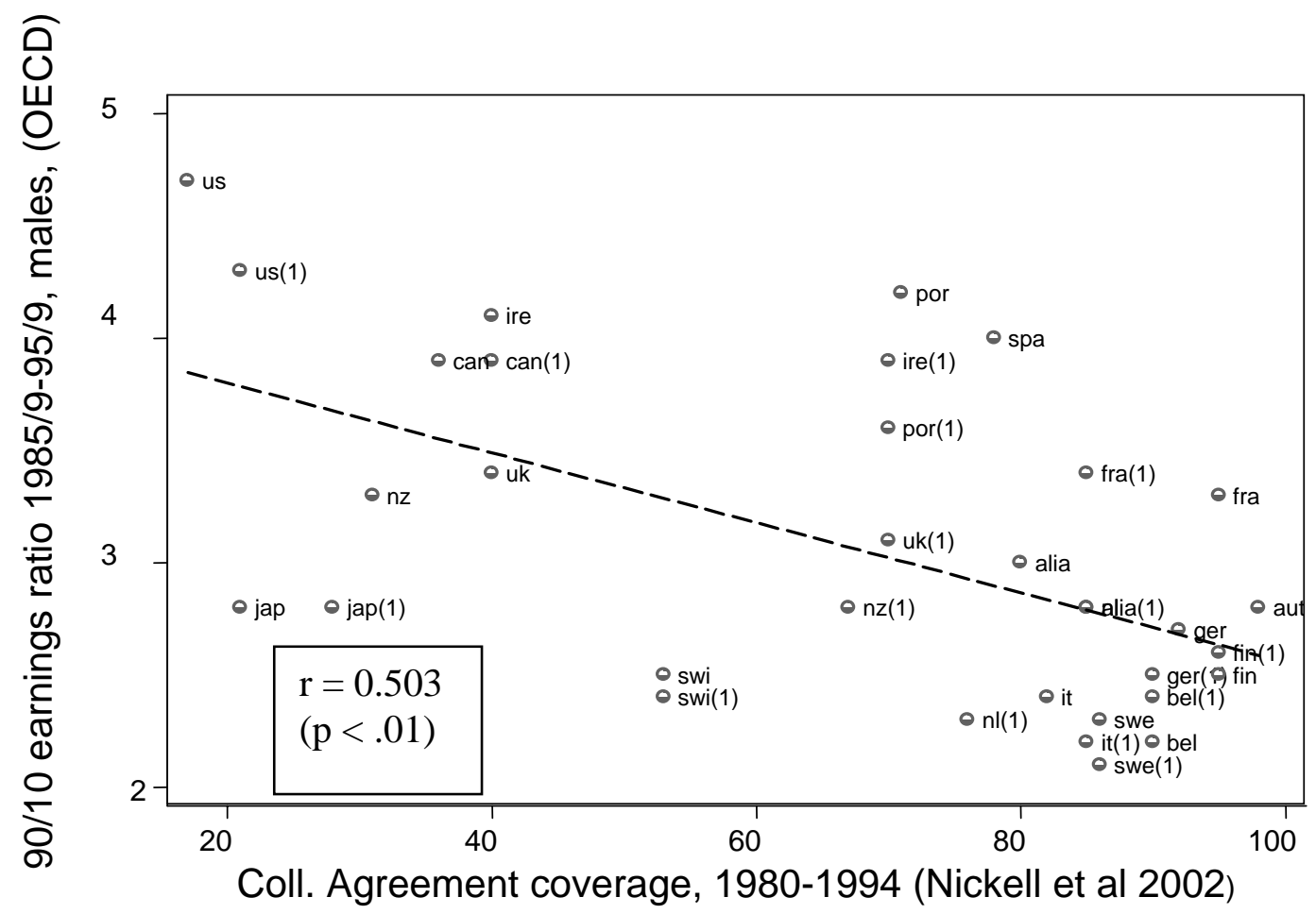

\section{Figure 1: Wage Differentials and Collective Agreement Coverage}

Note: each country except Austria (Aut) and Spain (Sp) has two observations, for the 1980s and 1990s, with the first signified by (1)

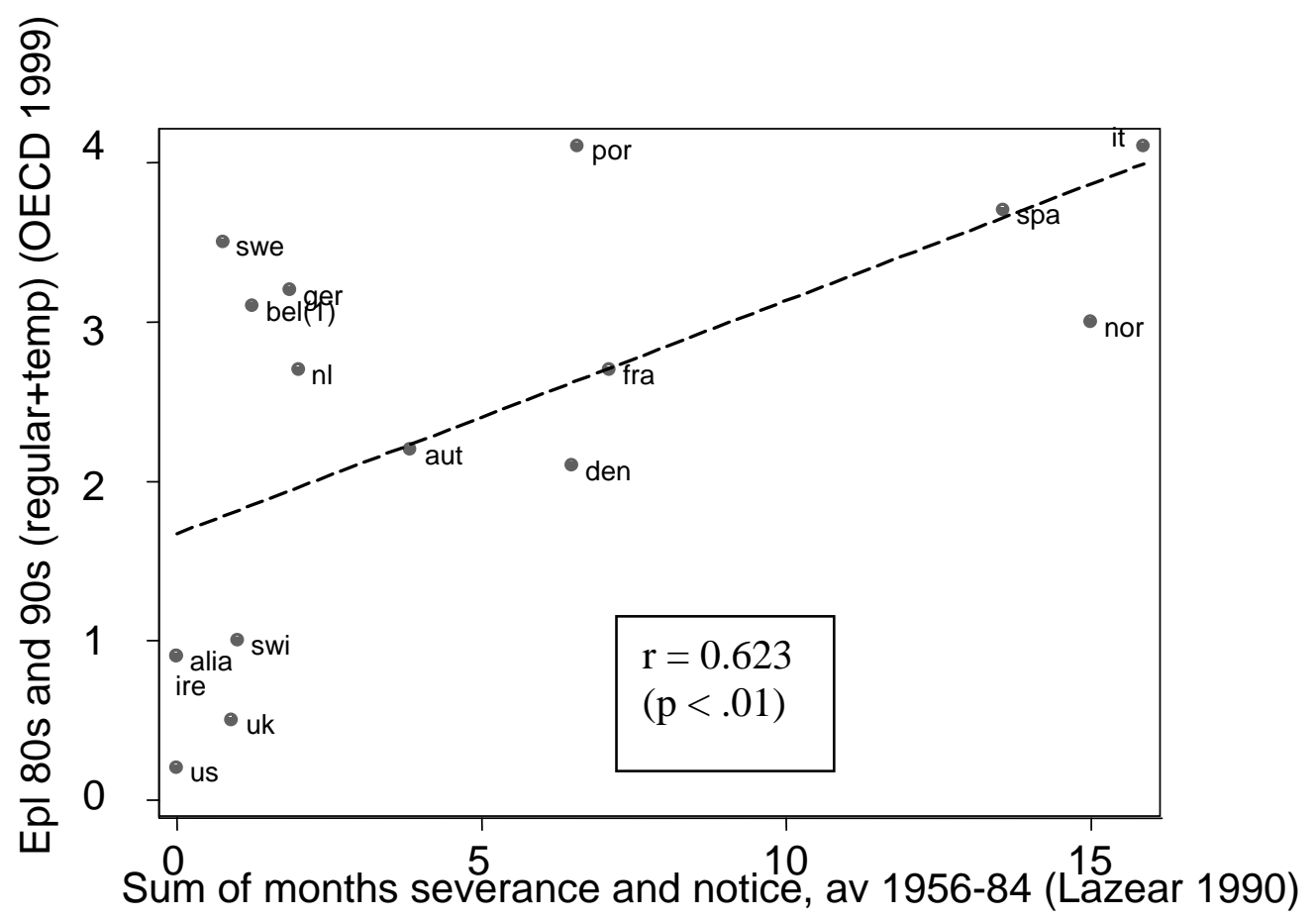

Note: the OECD employment protection index is based on indicators of difficulty of worker dismissal, including severance pay costs and procedural restrictions such as requirement for third party approval. It includes measures relating to both temporary and regular contracts. The Lazear index gives the months of severance pay and/or notice required to compensate a blue collar worker dismissed without cause after 10 years service.

\section{Figure 2: Employment Protection Measures Compared}




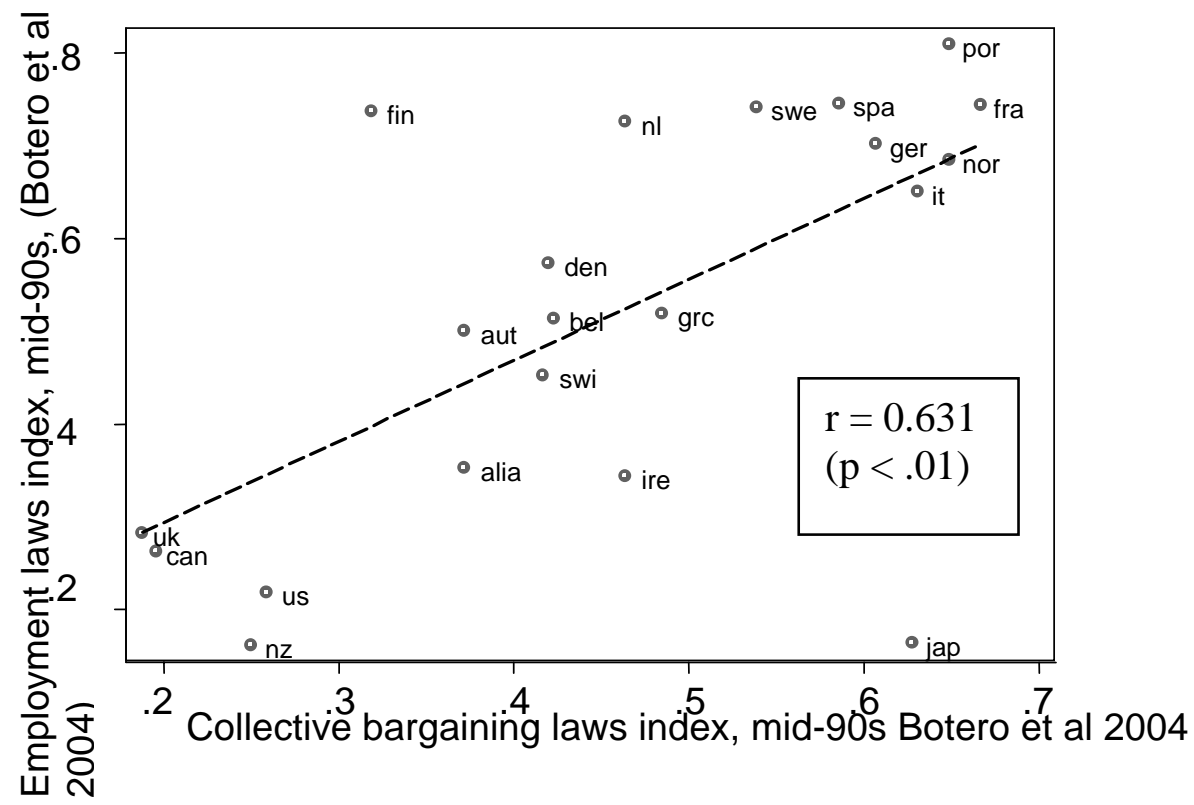

Note: the Botero et al (2004) employment protection index is made up in a similar way to the OECD’s. Their collective bargaining laws index is an average of indicators of protection such as extension of collective agreements, requirements for workers councils, non-replacement of striking workers, and legality of sympathy strikes.

Figure 3: Employment Protection and Union Protection Measures Compared

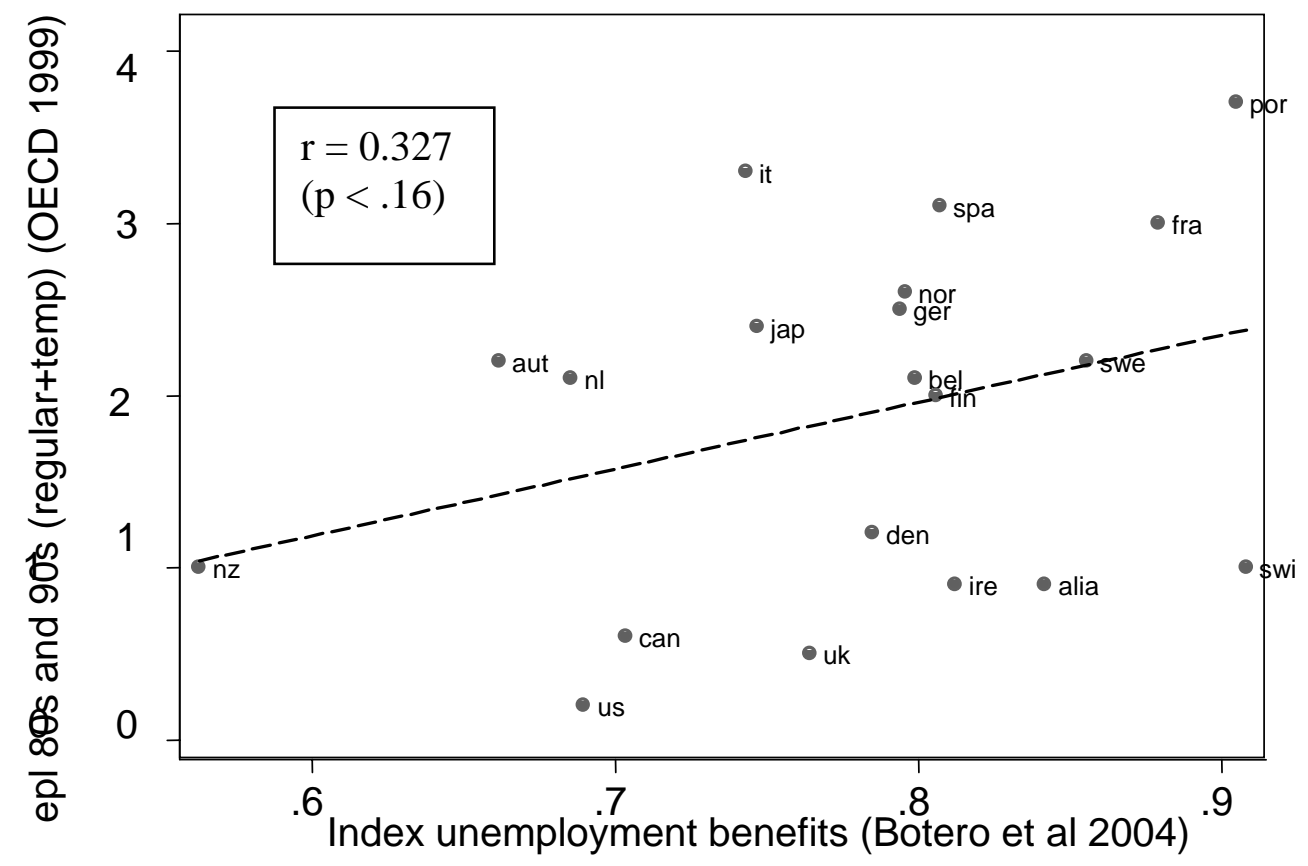

Note: the unemployment benefits index is an average of indices measuring aspects of the unemployment benefit including percentage of salary deducted, months required to qualify, waiting period for benefits, and the replacement rate for a 1 year unemployment spell.

Figure 4: Employment Protection and Unemployment Benefits Compared 


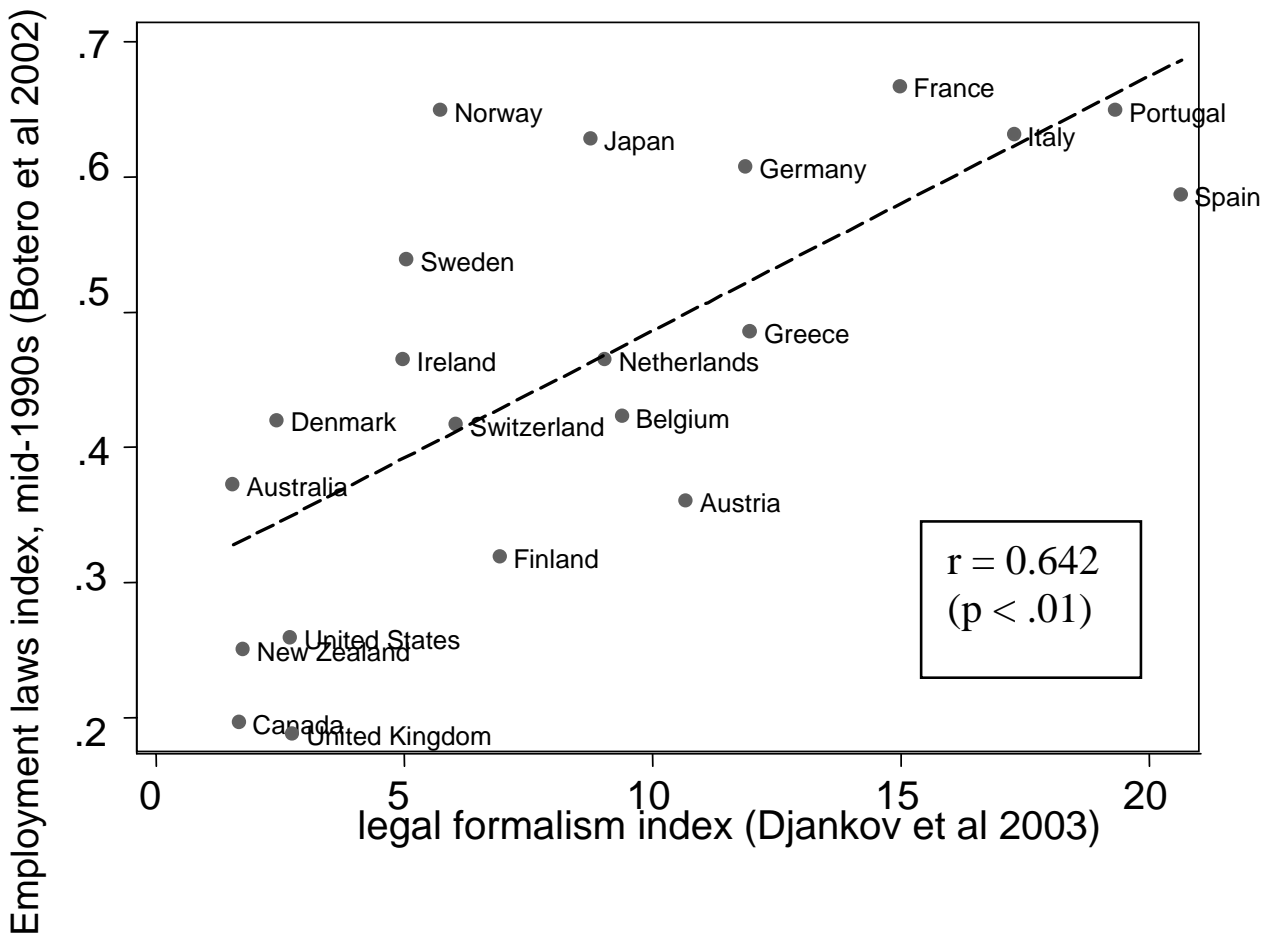

Note: the legal formalism index is the average of indexes measuring statutory intervention in lower-level civil cases for non-payment of rent, or for a bounced cheque, and the number of different procedures required to legally begin a business, the days required, and the costs - source is the Botero et al, 2004, website dataset.

\section{Figure 5: Employment Protection and Legal Formalism}


Table 1: Developments in EU Law on the Social Rights of Workers

\begin{tabular}{|c|c|c|}
\hline & $\begin{array}{l}1989 \text { Charter of Fundamental } \\
\text { Worker Rights } \\
\text { (see Addison and Siebert, 1991, } \\
\text { 1994a, 1999) }\end{array}$ & Subsequent Legislation \\
\hline $\begin{array}{l}\text { a) Freedom of } \\
\text { movement }\end{array}$ & $\begin{array}{l}\text { Workers posted to another EU } \\
\text { member state must receive host } \\
\text { country wages and conditions. }\end{array}$ & $\begin{array}{l}\text { Freedom of worker movement is part of Title III of the Treaty. "Posted workers" } \\
\text { directive passed as OJ L216 of 21.1.1997. The focus now is on portability of } \\
\text { social security benefits, and occupational pensions (EIRR, 2005). }\end{array}$ \\
\hline $\begin{array}{l}\text { b) Employment and } \\
\text { remuneration }\end{array}$ & $\begin{array}{l}\text { "Fair remuneration" and a "decent } \\
\text { standard of living" required, and } \\
\text { atypical (part-time and temporary) } \\
\text { contracts to be regulated to ensure } \\
\text { pro-rata wages and conditions. }\end{array}$ & $\begin{array}{l}\text { A framework agreement on part-time work eventually passed, OJ L14 of 20.1.98 } \\
\text { and L131 of 5.5.98. A proposed directive (COM(02)701) on agency workers is } \\
\text { still under discussion (DTI, 2003). } \\
\text { Note: no directives on minimum wages or extension of collective agreements. }\end{array}$ \\
\hline $\begin{array}{l}\text { c) Improvement of } \\
\text { living and working } \\
\text { conditions }\end{array}$ & $\begin{array}{l}\text { Minimum working conditions } \\
\text { including working hours, to be set. } \\
\text { Also, procedures developed to } \\
\text { protect workers in the event of } \\
\text { collective dismissals and } \\
\text { bankruptcies. }\end{array}$ & $\begin{array}{l}\text { 1) Working hours limited by directive OJ L307 of 13.12.1993, though UK } \\
\text { appealed to ECJ and only implemented on 23.11.1996. UK's opt-out now under } \\
\text { discussion (EU, 2004). } \\
\text { 2) Collective dismissals/redundancies legislation requiring information } \\
\text { disclosure to worker representatives goes back to } 1975 \text { (OJ L48 of 22.2.1975). } \\
\text { It was modified in } 1992 \text { (OJ L245 of 26.8.1992) and } 1998 \text { (OJ L225 of 12.8.98). } \\
\text { Currently there is a consultation on “socially intelligent” restructuring, linked to } \\
\text { further development of EWCs (EIRR, 2005). }\end{array}$ \\
\hline d) Social protection & $\begin{array}{l}\text { Every worker to have the right to } \\
\text { adequate social security benefits. }\end{array}$ & No directives. \\
\hline $\begin{array}{l}\text { e) Freedom of } \\
\text { association and } \\
\text { collective } \\
\text { bargaining }\end{array}$ & $\begin{array}{l}\text { Note: the unqualified right to } \\
\text { collective action (industrial disputes) } \\
\text { is not put forward, but is to remain } \\
\text { subject to national laws. }\end{array}$ & $\begin{array}{l}\text { The idea of "social dialogue" between management and labour at Community } \\
\text { level has steadily developed, and the EU Treaty (articles } 138 \text { and 139) provides } \\
\text { for the Commission to initiate social policy legislation via consultation with } \\
\text { management and labour. } \\
\text { Note: no directives promoting collective bargaining as such. }\end{array}$ \\
\hline $\begin{array}{l}\text { f) Vocational } \\
\text { training }\end{array}$ & $\begin{array}{l}\text { Every worker is to have access to } \\
\text { vocational training, and to receive it } \\
\text { throughout working life. }\end{array}$ & $\begin{array}{l}\text { The EU Structural Funds are used to co-finance training initiatives, though } \\
\text { whether they add much to already extensive member state efforts is doubtful } \\
\text { (Addison and Siebert, 1994b) }\end{array}$ \\
\hline
\end{tabular}




\begin{tabular}{|c|c|c|}
\hline $\begin{array}{l}\text { g) Equal treatment } \\
\text { for men and } \\
\text { women (and others) }\end{array}$ & $\begin{array}{l}\text { Note: the rights to "equal treatment” } \\
\text { required here were linked only to } \\
\text { gender. }\end{array}$ & $\begin{array}{l}\text { The right to equal treatment has been extended far beyond gender, and now } \\
\text { covers race, ethnic origin, religion, sexual orientation, disability and age (Article } \\
\text { 13). Race and origin are covered by directive OJ L180 of 19.7.2000, and the } \\
\text { remainder by OJ L303 of } 2.12 .2000 \text {, with a long period, until December } 2006 \\
\text { allowed for implementation of the controversial disability and age regulations. }\end{array}$ \\
\hline $\begin{array}{l}\text { h) Information, } \\
\text { consultation and } \\
\text { participation of } \\
\text { workers }\end{array}$ & $\begin{array}{l}\text { Information, consultation and } \\
\text { participation for workers must be } \\
\text { developed, especially regarding } \\
\text { technical change, mergers and } \\
\text { collective redundancies. }\end{array}$ & $\begin{array}{l}\text { 1) European Works Councils established in large transnationals by directive OJ } \\
\text { L } 254 \text { of } 30.9 .1994 \text { - excluding the UK until December 1997. This area is being } \\
\text { reconsidered by the Commission to advance "best practice" in industrial } \\
\text { restructuring (EIRR, 2005). } \\
\text { 2) Works councils required in all undertakings employing > } 50 \text { workers by } \\
\text { directive of OJ L } 80 \text { of } 23.3 .2002 \text {. UK regulations published } 2004 \text { (DTI 2004), to } \\
\text { cover undertakings employing > } 150 \text { by April 2005, > } 100 \text { by April 2007, and > } \\
50 \text { by April 2008. }\end{array}$ \\
\hline $\begin{array}{l}\text { i) Health protection } \\
\text { and safety at the } \\
\text { workplace }\end{array}$ & $\begin{array}{l}\text { All workers to enjoy satisfactory } \\
\text { health and safety conditions at the } \\
\text { workplace. }\end{array}$ & $\begin{array}{l}\text { This area predates the } 1989 \text { Charter, and there have been many directives. The } \\
\text { latest proposal covers optical radiation (EIRR, 2005), including "solar radiation" } \\
\text { which has raised opposition among UK building workers. }\end{array}$ \\
\hline $\begin{array}{l}\text { j) Protection of } \\
\text { children and } \\
\text { adolescents }\end{array}$ & $\begin{array}{l}\text { All child labour below minimum } \\
\text { school leaving age is banned, except } \\
\text { for non-arduous activities, and night } \\
\text { work is completely banned. }\end{array}$ & The directive OJ 1216 of 20.8.1994 secured these objectives. \\
\hline k) Elderly persons & $\begin{array}{l}\text { Elderly persons' incomes are to } \\
\text { offer a “decent standard of living”.. }\end{array}$ & $\begin{array}{l}\text { Several recommendations mention elderly people, but no directives beyond } \\
\text { discrimination above. }\end{array}$ \\
\hline 1) Disabled persons & $\begin{array}{l}\text { Disabled persons' are to have the } \\
\text { right to concrete measures (e.g. } \\
\text { training) to improve their social and } \\
\text { professional integration. }\end{array}$ & $\begin{array}{l}\text { No directives as such, but Article } 137 \mathrm{~g} \text { of the Treaty requires integration of } \\
\text { people excluded from the labour market, and } 137 \mathrm{j} \text { requires that social exclusion } \\
\text { be combated. }\end{array}$ \\
\hline m) NEW & $\begin{array}{l}\text { Article } 137 \mathrm{~d} \text { of the EU Treaty } \\
\text { requires Community support for } \\
\text { protection of workers where their } \\
\text { employment contract is terminated. }\end{array}$ & $\begin{array}{l}\text { Protection of individual workers against dismissal was not covered in the } 1989 \\
\text { Charter. However, this aim is part of the thinking behind both the agency } \\
\text { workers proposed directive (b above), and the new information and consultation } \\
\text { directive (h2 above). }\end{array}$ \\
\hline
\end{tabular}

Historical Note: In 1989, the Charter was supported in a declaration by all EU members except the UK, which eventually signed up in 1998. The Charter now appears in the consolidated Treaty Establishing the European Community as Title XI "Social policy, education, vocational training and youth”. 
Table 2: Labour Regulation and Jobs - Further Analysis

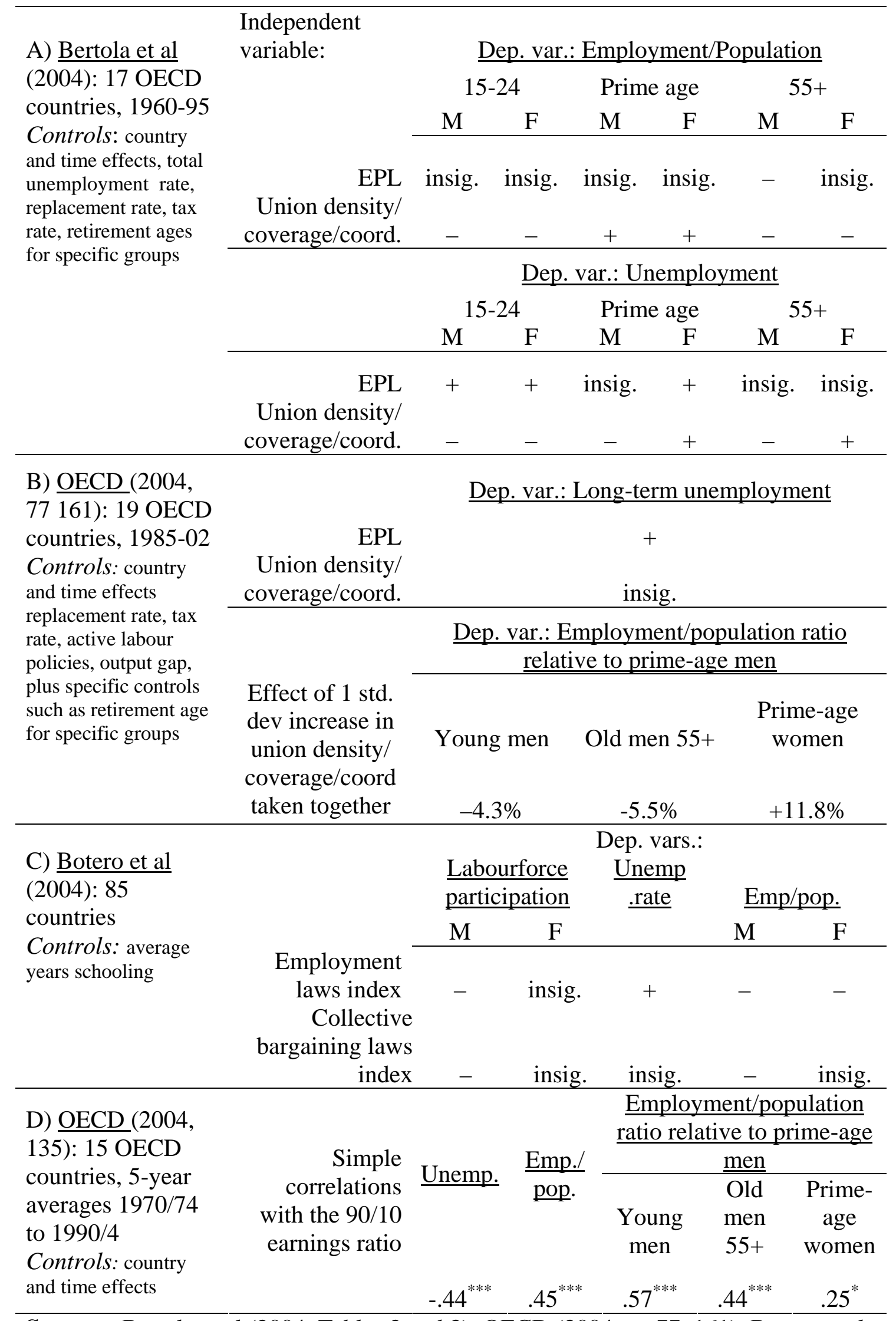

Sources: Bertola et al (2004, Tables 2 and 3); OECD (2004, pp 77, 161), Botero et al (2004, Table 8). 
Table 3: Plant-Level Hiring Decisions and Employment Protection

\begin{tabular}{lcccc}
\hline $\begin{array}{l}\text { Variable } \\
\text { (Mean) }\end{array}$ & $\begin{array}{c}\text { Average } \\
\text { Starting Age } \\
(30.1)\end{array}$ & $\begin{array}{c}\text { Standard } \\
\text { Deviation of } \\
\text { Starting Age } \\
(9.2)\end{array}$ & $\begin{array}{c}\text { Average } \\
\text { Education } \\
(11.4)\end{array}$ & $\begin{array}{c}\text { Standard } \\
\text { Deviation of } \\
\text { Education } \\
(1.6)\end{array}$ \\
\hline $\begin{array}{l}\text { Blanchard-Wolfers } \\
\text { employment protection }\end{array}$ & $(1)$ & $(3)$ & $(3)$ & $(4)$ \\
measure t-1 & -1.60 & $-9.12^{* * *}$ & $2.35^{* * *}$ & -1.40 \\
$(1.0)$ & $(-0.26)$ & $(-2.94)$ & $(3.13)$ & $(-1.43)$ \\
\hline Union density t-1 & 0.09 & $-0.21^{* *}$ & 0.01 & 0.01 \\
$(38.6)$ & $(0.46)$ & $(-1.96)$ & $(0.28)$ & $(0.28)$ \\
\hline Tax wedge $t-1$ & 0.18 & -0.11 & $0.11^{* * *}$ & 0.03 \\
$(33.1)$ & $(0.66)$ & $(-0.85)$ & $(2.80)$ & $(0.65)$ \\
\hline Observations & 148 & 153 & 148 & 147 \\
\hline
\end{tabular}

Source: Daniel and Siebert, 2005.

Notes: Estimation was for 11 plants in the US, UK, Italy, Belgium and the Netherlands over 1975-95. Controls included plant employment deviation from trend, and age of worker stock, and national pay in manufacturing, plus a dummy for the rise in school-leaving age for the education equations. Estimates for columns (1) and (3), have age and education estimated simultaneously, using three stage least squares. Observations are formed from characteristics of annual new hires of males on open-ended contracts, including those who became subsequently employed on an open-ended basis within a year. tvalues are given in parentheses, and *, ** and *** denote significance at the $10 \%, 5 \%$ and $1 \%$ levels. 
Table 4: Public Choice Analysis of Labour Regulation - Saint-Paul

\begin{tabular}{|c|c|c|c|}
\hline $\begin{array}{l}\text { Interest group } \\
\text { (illustrative } \\
\text { percent of } \\
\text { electorate) }\end{array}$ & $\begin{array}{l}\text { High minimum } \\
\underline{\text { wages (plus strong }} \text { trade unions) }\end{array}$ & $\begin{array}{l}\text { Policies: } \\
\text { Strict employment } \\
\text { protection }\end{array}$ & $\begin{array}{l}\text { High unemployment } \\
\underline{\text { benefits }}\end{array}$ \\
\hline $\begin{array}{l}\text { Skilled } \\
\text { workers } \\
(30 \%)\end{array}$ & $\begin{array}{l}\text { No (well above the } \\
\text { floor; not in unions; } \\
\text { also want more jobs } \\
\text { for unskilled who } \\
\text { are complements) }\end{array}$ & $\begin{array}{l}\text { Perhaps (buys the } \\
\text { unskilled off more } \\
\text { cheaply than } \\
\text { redistribution via } \\
\text { high taxes) }\end{array}$ & $\begin{array}{l}\text { Perhaps (not } \\
\text { directly affected } \\
\text { except via required } \\
\text { taxes) }\end{array}$ \\
\hline $\begin{array}{l}\text { Semi- and } \\
\text { unskilled } \\
(60 \%)\end{array}$ & $\begin{array}{l}\text { Yes (raises semi- } \\
\text { and unskilled wages; } \\
\text { also reduces } \\
\text { competition from } \\
\text { unemployed; unions } \\
\text { protect rents) }\end{array}$ & $\begin{array}{l}\text { Yes (maintains } \\
\text { current job; also } \\
\text { reduces competition } \\
\text { from unemployed) }\end{array}$ & $\begin{array}{l}\text { Yes (raises the } \\
\text { outside option, and } \\
\text { so the group wage) }\end{array}$ \\
\hline $\begin{array}{l}\text { Short-term } \\
\text { unemployed } \\
\text { and temp } \\
\text { workers (5\%) }\end{array}$ & $\begin{array}{l}\text { Perhaps (may } \\
\text { benefit if job is } \\
\text { landed) }\end{array}$ & $\begin{array}{l}\text { Perhaps (may } \\
\text { benefit if job is } \\
\text { landed) }\end{array}$ & $\begin{array}{l}\text { Yes (but not too high } \\
\text { since job openings } \\
\text { may fall) }\end{array}$ \\
\hline $\begin{array}{l}\text { Long-term } \\
\text { unemployed } \\
(3 \%) \\
\end{array}$ & $\begin{array}{l}\text { No (reduces job } \\
\text { openings) }\end{array}$ & $\begin{array}{l}\text { No (reduces job } \\
\text { openings) }\end{array}$ & $\begin{array}{l}\text { Yes (but not too high } \\
\text { since job openings } \\
\text { may fall) }\end{array}$ \\
\hline $\begin{array}{l}\text { Capitalists } \\
(2 \%)\end{array}$ & No & No & $N o$ \\
\hline
\end{tabular}

Sources: Saint-Paul (1996, 275ff), Saint-Paul (1997, 293), Saint-Paul (2000, 70, 128, 155, 219). 


\section{References}

Acemoglu D and S Johnson, 2003. “Unbundling Institutions”, NBER Working Paper 9934, Cambridge, MA: National Bureau of Economic Research.

Addison JT and W S Siebert, 1991. "The Social Charter of the European Community: Evolution and Controversies”, Industrial and Labour Relations Review, July, 44: 597-625.

Addison JT and W S Siebert, 1994a. "Recent Developments in Social Policy in the New European Union”, Industrial and Labour Relations Review, October, 48: 527.

Addison JT and W S Siebert, 1994b. "Vocational Training and the European Community”, Oxford Economic Papers, October, 46: 696-724.

Addison JT and W S Siebert, 1999. "Regulating European Labour Markets: More Costs than Benefits?”, Hobart Paper 138, London: Institute of Economics Affairs.

Agell J, 1999. “On the Benefits from Rigid Labour Markets: Norms, Market Failures and Social Insurance”, Economic Journal, February: F143-164.

Amable B and D Gatti, 2004. "The Political Economy of Job Protection and Income Distribution”, Discussion Paper 1404, Institute for Labour Research (IZA): Bonn

Becker G, 1956. The Economics of Discrimination. Chicago: University of Chicago Press.

Becker G, 1983. “A Theory of Competition Among Pressure Groups for Political Influence”, Quarterly Journal of Economics, August: 371-400.

Bertola G, F Blau and L Kahn, 2004. "Labor Market Institutions and Demographic Employment Patterns”, IZA Workshop on Wage Inequality, Technology and Institutions, http://www.iza.org/conference_files/witi_2004/kahn_l398.pdf.

Blanchard Olivier J. and Justin Wolfers J, 2000. "The Role of Shocks and institutions in the rise of European Unemployment: the Aggregate Evidence”, Economic Journal, March: C1-C33.

Boeri T, 1998. "Enforcement of Employment Security Regulations, On-the-job Search and Unemployment Duration”, European Economic Review, 43: 65-89.

Boeri T, J Ignacio, C Ruiz and V Galasso, 2004. "Cross-Skill Redistribution and the Tradeoff between Unemployment Benefits and Employment Protection” ”, Discussion Paper 1371, Institute for Labour Research (IZA): Bonn.

Botero, J, S Djankov, R La Porta, F Lopez-de-Silanes, and A Shleifer, 2004. "The Regulation of Labor”, Quarterly Journal of Economics, November: 1339-1382.

Daniel K and W S Siebert, 2005. "Does Employment Protection Reduce the Demand for Unskilled Labour?”, International Economic Journal, June: 197-222.

Djankov S, R La Porta, F Lopez-de-Silanes, and A Shleifer, 2003. “Courts”, Quarterly Journal of Economics, May: 453-517.

DTI, 2003. “Explanatory Memorandum on European Community Legislation Amended Proposal for a Directive of the European Parliament and of the Council on Temporary Work”, London: Department of Trade and Industry.

DTI, 2004. "Information and Consultation of Employees Regulations 2004”, London: Department of Trade and Industry.

EIRR, 2005. "Social Policy State of Play”, European Industrial Relations Review, July: 19-26.

EU, 2004. Proposal for a Directive of the European Parliament and of the Council Amending Directive 2003/88/EC Concerning Certain Aspects of the Organisation of Working Time, COM(2004) 607 final. 
EU, 2005. "Fundamental Rights within the European Union”, europa.eu.int/scadplus/leg/en/cha/c10107.htm.

Feld L, 2005. "Regulatory Competition and Federalism in Switzerland: Diffusion by Horizontal and Vertical Interaction”, Unpublished Paper, Philipps-University of Marburg.

Frey B and A Stutzer, 2000. “Happiness, Economy and Institutions”, Economic Journal, October: 918-938.

Financial Times, 2005a. "EU to review draft law on temps' rights”, George Parker, Sarah Laitner and Jean Eaglesham, September 24.

Financial Times, 2005b. "Employers fear consultation law”, Stephen Overell, FT.com site; March 2.

Glaeser E and A Shliefer, 2002. "Legal Origins”, Quarterly Journal of Economics, November: 1193-1229.

Gorter C, 2000. “The Dutch Miracle?”, in G Esping-Andersen and M Regini (eds.) Why Deregulate Labour Markets? Oxford: Oxford University Press.

Gray D, 1995. “All Displaced Workers Are Not Created Equal: The Political Economy of Worker Adjustment Assistance in France”, Public Choice, December: 313-333.

Grubb D, 2005. “Trends in Unemployment Insurance, Related Benefits and Active Labour Market Policies in Europe”, unpublished paper, Paris: OECD.

Grubb D and W Wells, 1993. "Employment Regulation and Patterns of Work in OECD Countries”, OECD Economic Studies, Winter.

Guelfi, A, 2004. Employment Protection and the Incidence of Unemployment: A Theoretical Framework, Labour, 18(1): 29-52.

Hayek, F A, 1960. The Constitution of Liberty, London: Routledge and Kegan Paul.

Jefferys, S, 2003. Liberté, Égalité and Fraternité at Work, Basingstoke: PalgraveMacmillan.

Josselin J-M and A Marciano, 2002. "Introduction: The Economics of the Constitutional Moment in Europe”, in J-M Josselin and A Marciano (eds.), The Economics of Harmonizing European Law, Cheltenham: Edward Elgar.

Koeniger W, M Leonardi and L Nunziata, 2004. "Labour Market Institutions and Wage Inequality, Discussion Paper 1295, Institute for Labour Research (IZA): Bonn

Lazear E, 1990. “Job Security Provisions and Employment”, Quarterly Journal of Economics, August: 699-726.

Laporta R, F Lopez-de-Silanes, A Shliefer and R Vishny, 1998. “Law and Finance”, Journal of Political Economy, December: 1113-55.

Nickell S, 1986. “Dynamic Models of Labour Demand”, in O Ashenfelter and R Layard (eds.), Handbook of Labor Economics, Amsterdam: North-Holland.

Nickell S, L Nunziata, W Ochel and G Qunintini, 2002. “The Beveridge Curve, Unemployment and Wages in the OECD from the 1960s to the 1990s”, CEP Discussion Paper 502, London School of Economics.

Nickell S, and G Quintini, 2003. “Nominal Wage Rigidity and the Rate of Inflation”, Economic Journal, 113 (October): 762-781.

Nicoletti G, R Haffner, S Nickell, S Scarpetta and G Zoega, 2001. "European Integration, Liberalisation and Labour Market Performance”, in G Bertola, T Boeri and G Nicoletti (eds.) Welfare and Employment in a United Europe, Cambridge, MA: MIT Press. 
North D, 1998. “The Rise of the Western World”, in P Bernholz, M E Streit, R Vaubel (eds), Political Competition, Innovation and Growth, Berlin: SpringerVerlag..

OECD, 1999. Employment Outlook 1999, Paris: Organisation for Economic Cooperation and Development.

OECD, 2004. Employment Outlook, 2004, Paris: Organisation for Economic Cooperation and Development.

Persson T, and G Tabellini, 2003, The Economic Effects of Constitutions, Cambridge, Mass.: MIT Press.

REC, 2002. Response of the Recruitment and Employment Confederation to the Department of Trade and Industry's Consultation on the Proposed Agency Workers Directive, http://www.rec.uk.com/rec/lobbying/AWDresponseOct2002.pdf.

Saint-Paul, G, 1996. "Labour Markets: How Reform Took Place”, Economic Policy, October: 263-316.

Saint-Paul, G, 1997. “The Rise and Persistence of Rigidities”, American Economic Review, May: 290-94.

Saint-Paul, G, 2000. The Political Economy of Labour Market Institutions, Oxford: Oxford University Press.

Saint-Paul, G, 2002. “The Political Economy of Employment Protection”, Journal of Political Economy, May: 672-704.

Siebert, W S, 1986. "Restrictive Practices in South Africa's Labour Market", Economic Affairs, October/November: 26-29.

Siebert W S, 1997. "Overview of European Labour Markets” in J T Addison and W S Siebert (eds.) Labour Markets in Europe, London: Harcourt Brace/Dryden.

Smith, Adam, 1982. Lectures on Jurisprudence (1766), R L Meek, D D Raphael and P G Stein (eds.), Indianapolis: Liberty Fund.

Times 2005. “Union anger as Britain retains EU working time opt-out”, June 02, 2005. 